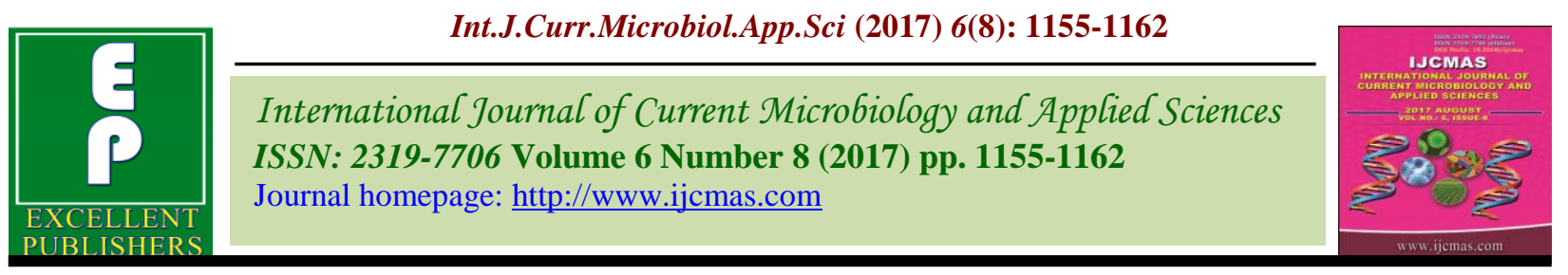

Original Research Article

https://doi.org/10.20546/ijcmas.2017.608.143

\title{
Socio-Economic Profile of Potato Growers in Etawah District, Uttar Pradesh, India
}

\author{
Shivam $^{1}$, R.K. Doharey ${ }^{1}$, S.N. Singh ${ }^{1}$, Manoj Kumar ${ }^{2 *}$, \\ Ashwani Kumar Verma ${ }^{1}$ and Vimlesh Kumar ${ }^{2}$ \\ ${ }^{1}$ Department of Extension Education, ${ }^{3}$ Department of Vegetable Science, N.D. University of \\ Agriculture and Technology, Kumarganj Faizabad-224229, U.P., India \\ ${ }^{2}$ Department of Agriculture Extension S.V.P University of agriculture and Technology, \\ Modipuram Meerut, U.P., India \\ *Corresponding author
}

A B S T R A C T

\begin{tabular}{|l|}
\hline Ke y w or d s \\
Potato growers, \\
Land holding, \\
Family income. \\
\hline Article Info \\
\hline Accepted: \\
17 June 2017 \\
Available Online: \\
10 August 2017 \\
\hline
\end{tabular}

India is second leading vegetable producing country in the world. Potato (Solanum tuberosum L.) is one of the major vegetable crops of the world. The present investigation was conducted with the objective to know the socio-economics of potato growers. Two blocks of viz., Bharpura and Mahewa of Etawah district, selected purposively. Two hundred respondents were selected from the ten villages, 20 respondents from each village. The study revealed that a maximum number of the respondents $(67.50 \%)$ were finding in the age group i.e. middle (33-53 years). The maximum i.e. 96.50 per cent of respondents were found to be literate, while 03.50 per cent were illiterate. The majority of the respondents were married $(96.50 \%)$ against it, $(3.50 \%)$ respondents were un-married. The maximum number of respondents $(31.50 \%)$ were belonging from the land holding category i.e. small farmers ( 1.0 to $2.0 \mathrm{ha}$ ) followed by 26.00 per cent respondents found in the category of medium farmers (2- 4 ha) in this study, respectively. The majority $(53.50 \%)$ of the respondents were from those families whose annual family income were between Rs. 50001 to 250000 and belonged from the medium categories followed by low categories viz., 26.50 per cent (Up to 50000) and only 20.50 percent respondent were who belong from High categories of income (200001 and above), respectively.

\section{Introduction}

Potato (Solanum tuberosum L.) is one of the major vegetable crops of the world. It is an important crop grown in winter season in plains of India its productivity varies considerably between the regions, between the area within a region and with the cultured practices even at high fertility level. Among the food crops, it ranks fourth in important next only to rice, wheat and corn covering about 21.22 million hectare and fifth in production yielding about 309.5 million tones after sugarcane, rice and maize. It is a crop of temperate region. It has acclimatized itself to a wide range of climate condition. The temperature require during the growth period of the potato is $18-20^{\circ} \mathrm{C}$.

The potato is grown in sandy to medium loam having $\mathrm{pH}$ range from 5.2 to 6.4 .

Etawah district is largest producer of potato but lack of the productivity and quality 
produce could not meet because the traditional farming practices.

The Etawah district produced 30 to $40 \%$ less yield comparatively to the neighbor districts namely, Kannouj, Farrukkabad and other high yielding district and research stations. This is a mainly due to lack of new technology developed by different research stations.

Now-a-days there is shift towards commercialization of agriculture and farmers are giving importance to commercial crops rather than other food crops. Vegetable cultivation is one such commercial field, which yields more income to the farmers.

Poor farm management practices are applied to the vegetables cultivation in India. The transfer of agricultural technology is in operation throughout the country, but the technology had not yet reached to the grass root level.

\section{Materials and Methods}

The district Etawah is located in central in Kanpur division of U.P. Etawah is located between 26.77' north latitude and the meridians 72.02 ' east longitude. This district surrounded western by the city Agra, and Firozabad. On the south by Jaloun and Bhind (M.P), the city is flanked for a short distance by city Mainpuri and remaning distance by the Kannauj and on the east district of Auraiya.

The district Etawah has 7 tehsil. And 8 development blocks covering small fraction of rural living as detailed below: Out of total reported area for land utilization in the district Etawah 225281ha. The net area sown during the year 2015-2016 was 148000 ha. Which was $67.60 \%$ of the total reported area in the same year during kharif crops, whereas the cropped area during the rabi season was 216060 ha of the net sown, respectively. The cropping intensity was $155 \%$ which is more than the average of whole U.P. state. Etawah sadar has two Communities developmental block, and Bharthana tehsil has four communities developmental block out of these, selective blocks namely Barhpura and mahewa have been selected for the study, purposively.

Barhpura community development block was established in the year 1962 and divided in to six village development officer's circle for effective implementation of development programmes. This block constitutes 10 Nyay Panchayat, 69 gram panchayat and 113 villages, covering an area of square k.m.

The total population of the block according to 2011 census was 156881, out of this 79603 Where male 77272 and females. From literacy point of view $69.233 \%$ were male and $37.32 \%$ females.

Mahewa community development block was established in the year 1958 and divided in to six village development officer's circle for effective implementation of development programmes. This block constitutes 11 Nyay Panchayat, 69 gram panchayat and 109 villages, covering an area of 2522 square KM. The total population of the block according to 2011 census was 155532, out of this 80430 Where male 75102 and females. From literacy point of view $64 \%$ were male and $34 \%$ females.

\section{Sampling design and selection of the respondents}

The Ex-post facto design was used to see the role of potato production grower rural farmer's. For this, the lists of all the farming families (having potato grower) of each selected village were prepared.

A sample of 200 farmers was selected through random sampling technique from the list of 10 selected villages of both the blocks equally. 


\section{Results and Discussion}

\section{Age of respondents}

It reveals from table 1 that the maximum number of respondents $(67.50 \%)$ was observed in middle age category followed by old $(17.00 \%)$ and young (15.50\%) respondents. The age range of the selected respondents is from 23 to 66 years. The mean age of the respondents were observed to be 42.80 years.

It can be said that the middle aged categories of the people are more engaged in potato farming in the study area. The results are in corroboration of findings of Kubrevi and Khare (2008).

\section{Caste}

The table 2 indicates that the maximum numbers of respondents were observed by $(41.00 \%)$ other backward caste followed by scheduled caste $(36.00 \%)$ and general caste (23.00\%), respectively. Thus it is concludes that the other backward caste were dominant in the study area.

\section{Literacy of respondents}

The table 3 focuses that literacy percentage of the respondents was observed to be $85.00 \%$ literate and $15.00 \%$ illiterate. Further, the distribution of literate respondents in descending order as order as $20.50 \%, 20.00$ $\%, 16.50 \% 16.00 \%, 13.50 \%, 13.50 \%$, for high school, middle school, can read and write intermediate, primary, graduate, respectively. It can be concluded that the maximum numbers of respondents was found literate (Shekhar and Chauhan, 2003).

\section{Marital status of respondents}

It is obvious from the table 4 that maximum number of the respondents were married
$(96.50 \%)$ against it $(3.50 \%)$ respondents were unmarried. The ratio between unmarried and married was 1:27.57.

Hence, it may be concluded that almost every farmers who attain the age of 28 years was married.

\section{Land holding}

The table 5 indicates that most of the respondents $31.50 \%$ was found in the land holding category as small farmer (1-2 ha), followed by $26.00 \%$ categories of medium farmer (2-4 ha), $25.50 \%$ in the categories of marginal $(<1$ ha) and $17.00 \%$ in the categories of large (4 ha and above), respectively. The average land holding of the respondents was found to be 4.5 hectare.

Thus, it may be said that small and medium farmers are more than others in the study area.

\section{Family type}

The table 6 shows that joint families are more than in nuclear families. In terms of percentage $57.50 \%$ respondents belong to joint type families and $42.50 \%$ belong to nuclear type of families system.

\section{Family size}

It is evident from table 7 that $50.50 \%$ of the respondents families were observed such who 6-12 members in their family had followed by $29.50 \%$ family having up to 5 members and only $20.00 \%$ respondents family having 13 and above members in their family.

The average size of the family was 8 members. The range between minimum and maximum number of family members recorded from 4 to 16 .

The present results in conformity of report of Zekri et al., (2010). 
Table.1 Distribution of the respondents according to age

\begin{tabular}{|c|c|c|c|}
\hline \multirow{2}{*}{ S. No. } & Age group (years) & \multicolumn{2}{c|}{ Respondents } \\
\cline { 3 - 4 } & & Number & Percentage \\
\hline 1. & Young age (Up to 32 years) & 31 & 15.50 \\
\hline $\mathbf{2 .}$ & Middle age (33 - 53 years) & 135 & 67.50 \\
\hline 3. & Old age (54 and above years) & 34 & 17.00 \\
\hline \multicolumn{2}{|c|}{ Total } & $\mathbf{2 0 0}$ & $\mathbf{1 0 0 . 0 0}$ \\
\hline
\end{tabular}

Mean $=42.80$, S.D. $=10.57$, Range - Min. $=23$ Max. $=66$

Table.2 Distribution of the respondents according to caste

$\mathrm{N}=200$

\begin{tabular}{|c|l|c|c|}
\hline S. No. & \multirow{2}{*}{ Categories } & \multicolumn{2}{|c|}{ Respondents } \\
\cline { 3 - 4 } & & Number & Percentage \\
\hline 1. & General caste & 46 & 23.00 \\
\hline $\mathbf{2 .}$ & Other Backward caste & 82 & 41.00 \\
\hline 3. & Scheduled caste & 72 & 36.00 \\
\hline & Total & $\mathbf{2 0 0}$ & $\mathbf{1 0 0 . 0 0}$ \\
\hline
\end{tabular}

Table.3 Distribution of the respondents according to education

\begin{tabular}{|c|c|c|c|}
\hline \multirow{2}{*}{ S. No. } & \multirow{2}{*}{ Categories } & \multicolumn{2}{|c|}{ Respondents } \\
\hline & & Number & Percentage \\
\hline 1. & Illiterate & 30 & 15.00 \\
\hline 2. & Literate & 170 & 85.00 \\
\hline & Total & 200 & 100 \\
\hline 2. a. & Can read and write & 33 & 16.50 \\
\hline b. & Primary & 27 & 13.50 \\
\hline c. & Middle school & 40 & 20.00 \\
\hline d. & High school & 41 & 20.50 \\
\hline e. & Intermediate & 32 & 16.00 \\
\hline f. & Graduate & 27 & 13.50 \\
\hline & Total & 200 & 100.00 \\
\hline
\end{tabular}

Table.4 Distribution of the respondents according to marital status

\begin{tabular}{|c|c|c|c|}
\hline \multirow{2}{*}{ S. No. } & \multirow{2}{*}{ Categories } & \multicolumn{2}{|c|}{ Respondents } \\
\hline & & Number & Percentage \\
\hline 1. & Unmarried & 7 & 3.50 \\
\hline 2. & married & 193 & 96.50 \\
\hline & Total & 200 & 100.00 \\
\hline
\end{tabular}


Table.5 Distribution of the respondents according to land holding

\begin{tabular}{|c|l|c|c|}
\hline \multirow{2}{*}{ S. No. } & \multicolumn{2}{|c|}{ Categories (ha) } & \multicolumn{2}{|c|}{ Respondents } \\
\cline { 3 - 4 } & Mumber & Percentage \\
\hline 1. & Marginal (below 1 ha) & 51 & 25.50 \\
\hline $\mathbf{2 .}$ & Small (1-2 ha) & 63 & 31.50 \\
\hline 3. & Medium (2-4 ha) & 52 & 26.00 \\
\hline 4. & Large (4 ha and above) & 34 & 17.00 \\
\hline & Total & $\mathbf{2 0 0}$ & $\mathbf{1 0 0 . 0 0}$ \\
\hline
\end{tabular}

Mean-2.93, Min- 1, Max- 5,

Table.6 Distribution of the respondents according to family type

\begin{tabular}{|c|c|c|c|}
\hline \multirow{2}{*}{ S. No. } & Categories & \multicolumn{2}{|c|}{$\mathrm{N}=200$} \\
\cline { 3 - 4 } & & Number & Percentage \\
\hline 1. & Nuclear family & 85 & 42.50 \\
\hline $\mathbf{2 .}$ & Joint family & 115 & 57.50 \\
\hline & Total & $\mathbf{2 0 0}$ & $\mathbf{1 0 0 . 0 0}$ \\
\hline
\end{tabular}

Table.7 Distribution of the respondents according to size of family

\begin{tabular}{|c|l|c|c|}
\hline \multirow{2}{*}{ S. No. } & Categories & \multicolumn{2}{|c|}{ Respondents } \\
\cline { 3 - 4 } & & Number & Percentage \\
\hline $\mathbf{1 .}$ & Small (up to 5 members) & 59 & 29.50 \\
\hline $\mathbf{2 .}$ & Medium (6-12) & 101 & 50.00 \\
\hline $\mathbf{3 .}$ & Large (13 and above) & 40 & 20.00 \\
\hline & Total & $\mathbf{2 0 0}$ & $\mathbf{1 0 0 . 0 0}$ \\
\hline
\end{tabular}

Mean $=1.96$, S.D. $=0.76$, Range-Min. $=4$, Max. $=16$

Table.8 Distribution of the respondents according to experience of potato production

\begin{tabular}{|c|l|c|c|}
\hline \multirow{2}{*}{ S. No. } & Categories Experience (years) & \multicolumn{2}{c|}{ Respondents } \\
\cline { 3 - 4 } & & Number & Percentage \\
\hline 1. & Low experience (up to 8 year) & 25 & 12.50 \\
\hline 2. & Medium experience (8 -16 year) & 110 & 55.00 \\
\hline 3. & High experience (16 and above years) & 65 & 32.50 \\
\hline & Total & $\mathbf{2 0 0}$ & $\mathbf{1 0 0 . 0 0}$ \\
\hline
\end{tabular}

Mean $=12.33, \mathrm{SD}=2.98$, Range- Min. $=3$ Max. $=35$

Table.9 Distribution of the respondents according to annual income

\begin{tabular}{|c|c|c|c|}
\hline \multirow{2}{*}{ S. No. } & Categories & \multicolumn{2}{c|}{$\mathrm{N}=200$} \\
\cline { 3 - 4 } & & Number & Pespondents \\
\hline 1. & Low (up to 50000) & 53 & 26.50 \\
\hline $\mathbf{2 .}$ & Medium (50001-250000) & 107 & 53.50 \\
\hline 3. & High (250001 and above) & 40 & 20.00 \\
\hline & Total & $\mathbf{2 0 0}$ & $\mathbf{1 0 0 . 0 0}$ \\
\hline
\end{tabular}

Mean $=176865$, S.D $=105308$, range- Min. $=35000$, Max $=500000$, 
Table.10 Distribution of the respondents according to occupation

\begin{tabular}{|c|c|c|c|c|c|}
\hline \multirow{3}{*}{ S. No. } & \multirow{3}{*}{ Categories } & \multicolumn{4}{|c|}{ Respondents } \\
\hline & & \multicolumn{2}{|c|}{ Main occupation } & \multicolumn{2}{|c|}{ Subsidiary occupation } \\
\hline & & Number & Percentage & Number & Percentage \\
\hline 1. & Agriculture labour & 25 & 12.50 & 20 & 10.00 \\
\hline 2. & Caste based occupation & 12 & 6.00 & 29 & 14.50 \\
\hline 3. & Service & 40 & 20.00 & 28 & 14.00 \\
\hline 4. & Agriculture & 92 & 46.00 & 80 & 40.00 \\
\hline 5. & Agro-based enterprise & 20 & 10.00 & 22 & 11.00 \\
\hline 6. & Business & 11 & 5.5 & 5 & 2.50 \\
\hline & Total & 200 & 100.00 & 184 & 92.00 \\
\hline
\end{tabular}

Table.11 Distribution of the respondents according to social participation

\begin{tabular}{|c|l|c|c|}
\hline \multirow{2}{*}{ S. No. } & \multicolumn{1}{|c}{ Categories } & \multicolumn{2}{c|}{ Respondents } \\
\cline { 3 - 4 } & \multicolumn{1}{|c|}{ Number } & Percentage \\
\hline $\mathbf{1 .}$ & No participation & 19 & 9.50 \\
\hline $\mathbf{2 .}$ & Participation in one organization & 74 & 37.00 \\
\hline $\mathbf{3 .}$ & Participation in two organization & 46 & 23.00 \\
\hline $\mathbf{4 .}$ & Participation in more than two organization & 12 & 6.00 \\
\hline 5. & Office bearer $\quad$ Total & 49 & 24.5 \\
\hline & \multicolumn{2}{|c|}{} \\
\hline
\end{tabular}

Table.12 Distribution of the respondents according to housing pattern

\begin{tabular}{|c|c|c|c|}
\hline \multirow{2}{*}{ S. No. } & \multirow{2}{*}{ Categories } & \multicolumn{2}{|c|}{ Respondents } \\
\hline & & Number & Percentage \\
\hline 1. & Kuccha & 5 & 2.5 \\
\hline 2. & Mixed & 56 & 28.00 \\
\hline 3. & Pucca & 139 & 69.50 \\
\hline & Total & 200 & 100.00 \\
\hline
\end{tabular}

Table.13 Distribution of respondents about risk orientation

$$
\mathrm{N}=200
$$

\begin{tabular}{|c|l|c|c|}
\hline \multirow{2}{*}{ S. No. } & \multirow{2}{*}{ Categories (Score wise) } & \multicolumn{2}{|c|}{ Respondents } \\
\cline { 3 - 4 } & & Number & Percentage \\
\hline 1. & Low (up to 19) & 40 & 20.00 \\
\hline $\mathbf{2 .}$ & Medium (20 to 25) & 118 & 59.00 \\
\hline 3. & High (26 and above) & 42 & 21.00 \\
\hline & Total & $\mathbf{2 0 0}$ & $\mathbf{1 0 0 . 0 0}$ \\
\hline
\end{tabular}

Mean $=21.69$, S.D. $=3.16$, Min. $=15$, Max. $=29$ 
Table.14 Distribution of respondents about economic motivation

\begin{tabular}{l|c|c|c|}
\hline \multirow{2}{*}{ S. No. } & Categories (Score wise) & \multicolumn{2}{|c|}{ Respondents } \\
\cline { 3 - 4 } & & Number & Percentage \\
\hline 1. & Low (up to18) & 18 & 9.00 \\
\hline $\mathbf{2 .}$ & Medium $(19$ to 24$)$ & 131 & 65.50 \\
\hline 3. & High $(25$ to above) & 41 & 20.50 \\
\hline & Total & $\mathbf{2 0 0}$ & $\mathbf{1 0 0 . 0 0}$ \\
\hline &
\end{tabular}

\section{Experience of potato production}

It revealed from the table 8 that the maximum number of respondents $(55.00 \%)$ was observed in medium experience category followed by high experience $(32.50 \%)$ and low experience $(12.50 \%)$ respondents. The experience year range of the selected respondents from 5 to 30 year the mean experience of the respondents was observed to be years. It can be said that the medium experience categories of the people more engaged in potato farming in the study area.

\section{Annual income}

It is obvious from table 9 that maximum $(53.50 \%)$ of the respondents were from those families whose annual income were found in the categories of Rs. 50001 to 250000 and belonged from the medium categories followed by low categories viz., 26.50 per cent (Rs. up to 50000) and only 20.00 per cent respondent were who belonged from high categories of income Rs. 250001 and above, respectively. The present results in conformity of report Peer et al., (2013).

\section{Occupation}

It is evident from the table 10 that the maximum $46.33 \%$ respondent was observed such who had their main occupation as agriculture followed by service $20.00 \%$, agriculture labour $12.50 \%$, Agro based enterprise $10.00 \%$, caste based occupation
$6.00 \%$ business $5.50 \%$ and, as main occupation, respectively.

The maximum $40.00 \%$ respondent was observed such who had their subsidiary occupation as agriculture followed by 14.50 $\%$ respondent caste based occupation, $14.00 \%$ service, enterprise, $11.00 \%$ agro-based enterprise, 10.00 agriculture labour, and $2.50 \%$ business and as subsidiary occupation, respectively. On the basis of data, it can be said that agriculture is the main and subsidiary occupation of rural people.

\section{Social participation}

The table 11 indicates that the $37.00 \%$ of the respondents participates in one organization followed by $24.50 \%$ respondent's office bearer, $23.00 \%$ respondents Participation in two organizations, $6.00 \%$ respondents participation and $9.50 \%$ did not take any participation in more than two organizations, respectively. It means that majority of the respondents did have more interest of one participating in the one social organization.

\section{Housing pattern}

The table 12 indicates that $69.50 \%$ majority of the respondents reported having pucca type house followed by $28.00 \%$ respondent mixed and $2.50 \%$ respondents having kuchha, housing pattern respectively. It means that this area was having pucca type of housing pattern. 


\section{Risk orientation}

It is apparent from the table 13 that the maximum number of $59.00 \%$ respondents was having medium level of risk orientation while $21.00 \%$ and $20.00 \%$ respondents were found in the categories of high and low levels of risk orientation, respectively. The average mean of scores for risk orientation observed to be 21.69. Hence it can be concluded that the respondents was have medium level of bearing risk relating to important vegetable farming system.

\section{References}

Kubrevi, S. S. and Khare, N. K. (2008). Profile of the farmers towards potato farming in block Chadoora district
Budgam (Jammu and Kashmir). Environment and Ecology; 26(3A):1417-1419.

Peer, Q.J. A., Ahmad, N., Kaur, J., Chesti, M. H., Ahmad, H. S., Bhat, A; and Bhat, B. A. (2013). Study on economics of potato growing towards livelihood security. Afr. J. Agric. Res. 8(45): 56395644

Shekhar, D and Chauhan,J. (2003). Constraints in adoption of tobacco production. Indian Res. J. of Ext. Educ.3 (1): 28-29.

Zekri, S., Al-Rawahy, S. A. and Naifer, A. (2010). Socio-economic considerations of salinity: descriptive statistics of the Batinah. Journal of Research and Applications in Agricultural Engineering, 52(4):5-9.

\section{How to cite this article:}

Shivam, R.K. Doharey, S.N. Singh, Manoj Kumar, Ashwani Kumar Verma and Vimlesh Kumar. 2017. Socio-Economic Profile of Potato Growers in Etawah District, Uttar Pradesh. Int.J.Curr.Microbiol.App.Sci. 6(8): 1155-1162. doi: https://doi.org/10.20546/ijcmas.2017.608.143 